\title{
Analyze the Problems Existing in English Information Teaching and Study the Countermeasures
}

\author{
Dan Xu \\ Faculty of International Studies, Henan Normal University, Xinxiang, China \\ Email:x_dan@foxmail.com
}

How to cite this paper: Xu, D. (2021). Analyze the Problems Existing in English Information Teaching and Study the Countermeasures. Creative Education, 12, 1590-1599. https://doi.org/10.4236/ce.2021.127120

Received: June 10, 2021

Accepted: July 11, 2021

Published: July 14, 2021

Copyright $\odot 2021$ by author(s) and Scientific Research Publishing Inc. This work is licensed under the Creative Commons Attribution International License (CC BY 4.0).

http://creativecommons.org/licenses/by/4.0/

\begin{abstract}
Informatization of education is the inevitable development of the times. The rapid development of information technology is constantly changing people's life, work and thinking methods, and at the same time changing the way of teaching English. Modern information technology is undergoing a transition from assisted teaching to leading teaching, and the existing problems in English classroom teaching will become more prominent. This article starts with the analysis of the existing problems in English informatization teaching, and systematically summarizes the existing problems in four aspects: Students' information literacy is low, and their independent learning ability needs to be improved; Teachers' information literacy is insufficient, and their ability to apply information technology urgently needs to be strengthened; Insufficient innovation of English informatization teaching model and poor teaching methods; The structure of English informatization teaching content needs to be improved. It further analyzes the three main reasons for the existing problems: The quality and learning ability of students vary; Teachers have insufficient knowledge and use of informatization teaching; The infrastructure construction and basic conditions of English informatization teaching are relatively weak. Finally, a solution based on the strategies of intensive training to continuously improve teachers' informatization teaching technology, integrating resources to effectively improve English informatization teaching content, and innovative ideas to optimize the school's English informatization teaching environment, provides theoretical support for promoting the healthy development of English education.
\end{abstract}

\section{Keywords}

Educational Information, English Teaching, Problem Analysis, Coping Strategies 


\section{Introduction}

Educational informatization is the inevitable development of the times, one of the strategic priorities of China's informatization development, and the only way to modernize education. The rapid development of information technology is constantly changing people's life, work and way of thinking, as well as teaching. Especially in the past ten years, college English teaching has been closely linked with modern information technology. The computer-based, classroom-based college English teaching model has been widely promoted across the country, which has improved the overall level of college English teaching (Hamidi \& Chavoshi, 2018). However, in the process of the gradual transition of modern information technology from auxiliary teaching to leading teaching, college English classroom teaching also has some urgent problems to be solved. The teacher's information teaching ability is an important part of the teacher's ability, and it is of great significance to improve the teacher's overall teaching ability. Improving the information teaching ability of high school English teachers will help to enhance the effectiveness of English teaching, promote the professional development of English teachers themselves, and help bring more information technology advantages and make English classrooms more intelligent (Sun, Lin, You et al., 2017).

This article takes as the starting point to improve the training quality of undergraduate graduates, and closely focuses on the theme of undergraduate college English information teaching. This article systematically studies the main problems of undergraduate English teaching informatization, analyzes the causes of the problems, and proposes countermeasures for the cultivation of high-level, high-quality applied talents in Chinese universities.

\section{Definition of Informationized Teaching Concept}

Information teaching is what we usually call "electrified teaching". Informatization teaching refers to the bilateral activities in which educators and learners rely on informatization thinking and concepts, with the help of modern educational media, information networks, information resources and methods, to promote better teaching. Informationization is the attribute, and the central word is teaching. It not only emphasizes the teaching activities of teachers and students using modern educational media technology, but also pays attention to the bilateral teaching activities of interactive communication between teachers and students through information technology. The academic circle has not yet given a clear definition of information teaching. The more recognized definition of informatization teaching is: informatization teaching refers to teaching activities that are supported by modern teaching concepts, intermediary by information technology means, and adopt modern teaching methods (Hao, Dennen, \& Li, 2017). Some scholars define informatization teaching as a teaching method that integrates information technology, modern teaching concepts, modern teaching methods, and subject knowledge to promote the common development of 
teachers and students. The informatization teaching concept we are concerned about emphasizes the intensity of information literacy of teachers and students, the concept of informatization teaching, and the auxiliary teaching methods of information technology such as computers and multimedia.

\subsection{Definition of English Informatization Teaching Concept}

English informatization teaching focuses on the informatization process of English teaching. It refers to the integration of modern educational concepts in the process of English teaching, the use of information technology to make English teaching advance with the times, and the gradual realization of the integration of information technology and English subjects under the guidance of information concepts (Ma \& Zhang, 2021).

\subsection{The Significance of English Informatization Teaching}

Information teaching is a modern teaching method based on information technology and applied to teaching. The significance of information-based English teaching lies in: First, through the implementation of information-based teaching, innovating traditional English classroom teaching methods, changing traditional English classroom teaching methods, incorporating modern educational technology concepts into curriculum teaching, and relying on information technology to assist English teaching in English Inject vivid graphic information into the classroom to stimulate students' interest in learning English from a new perspective. The second is to use information-based teaching methods to create a more realistic teaching situation, create a learning environment that easily meets the needs of students, and improve students' English application ability (Sun, Yao, You et al., 2018). For example: master students' preferences and cognitive characteristics, play video materials that meet the teaching requirements and are suitable for students to learn in the classroom, and can effectively show the real life scenes of people in English-speaking countries, thereby creating a learning environment with practical purposes and enhancing Teaching effect. Third, in the process of informatization English teaching, relying on modern educational technology with extremely rich information storage, the effective integration of graphics, audio, and video, compared with the traditional English teaching mode, effectively saves teachers' writing time and highlights at the same time. The importance and application value of information technology in English teaching are difficult to teach. Enrich the content of classroom learning and improve the efficiency of English teaching (Smit \& Engeli, 2015).

\subsection{Information Technology and Curriculum Integration}

Information technology and curriculum integration refers to a new teaching method that integrates information resources, information technology and curriculum teaching under the guidance of modern education theories and under the premise of grasping certain integration concepts and concepts, promotes the 
effective completion of classroom teaching tasks (Wu, 2020). Integration pays more attention to the integration of ideas. It is the integration of information technology and subject courses, with cultural characteristics, literacy, knowledge and skills. It is a teaching mode with modern information technology as the medium. This teaching model is not only conducive to the effective play of the leading role of teachers, but also fully and reasonably reflects the main status of students, and fundamentally innovates the traditional teaching concepts, teaching concepts, and the learning goals, teaching goals, and teaching goals guided by concepts. Create a good learning environment for students, so that they can choose effective information technology means to obtain, and comprehensively compare information, learn the corresponding subject professional knowledge, and cultivate the corresponding practical application ability, regardless of the learning stage (Wen, 2018).

The information technology and curriculum integration discussed in this research refers to changing the traditional teaching structure under the guidance of modern education concepts, using modern information technology as the medium to create a new teaching model that fully reflects the "dual roles" of teachers and students. The teaching mode of subject combination effectively builds a classroom teacher-student community.

\section{The Main Problems Existing in the Current English Information Teaching}

\subsection{Students' Information Literacy Is Low, and Their Independent Learning Ability Needs to Be Improved}

With the popularization of information technology and the gradual improvement of higher education information teaching, college students' information awareness has gradually increased, but there is still a certain distance from the requirements of the information age for students' information ability (Wang \& $\mathrm{Ma}, 2020)$. On the one hand, college students have different qualities and learning abilities, different starting points for foreign language learning, students' overall English foundation is relatively weak, and the long-term insufficient environment affects their own interest and enthusiasm for English learning. On the other hand, on this basis, it is difficult to talk about the integration of information technology and English learning, especially for freshmen entering the university, which requires a long period of adjustment and adaptation. Different from the teaching model of compulsory education, students will maintain a certain sense of freshness and curiosity in the learning of various subjects, but the level of information literacy of students is generally low. The survey data shows that up to $42.0 \%$ of students said they did not understand information-based teaching and were generally interested in the application of information-based teaching methods in English teaching. Students only stay in the literal understanding of information teaching, without certain information awareness. The ability of information technology to be applied to subject learning is insufficient, 
and the proportion of students who actively use computers and other multimedia devices to learn English is only $7.40 \%$. The students have not received systematic information theory and technical training, and their overall information literacy is low, and their practical application ability needs to be improved.

At present, although undergraduate colleges and universities have basically determined the general development direction of undergraduate colleges and universities, under such a background, especially the advent of the "Internet+" era, there are still many shortcomings in English informatization teaching. Through on-site investigations and private interviews with some students, the author found that there are deviations in students' autonomous learning ability, and unclear learning goals are a serious problem. The survey shows that the proportion of students taking online courses is $14.40 \%$, the proportion of learning English is $7.40 \%$, the proportion of watching movies and listening to songs is $27.60 \%$, and the proportion of playing games and chatting is $18.90 \%$. It can be seen from this result that although students have mastered certain computer and network technology application skills, nearly half of the students are still doing things that have nothing to do with English learning. 59.80\% of students are not interested in English learning, and $55.80 \%$ of students have no clear goals. It can be seen that the students' enthusiasm for learning English is not high, and their autonomous learning ability is biased. Although there is a lot of internet time, only a small proportion of students are learning English-related content. Although $25.90 \%$ of students search for relevant information online, their ability to identify and analyze information is quite lacking. Combining these data, I learned that although most students search for relevant information on search engines such as Baidu, they lack the ability to filter effective information. The fundamental reason is that students lack information literacy, which makes them unable to improve their ability to search for information. In addition, students themselves are not aware of their self-study needs, so they cannot use the Internet to learn more effectively.

\subsection{Teachers' Information Literacy Is Insufficient, and Their Ability to Apply Information Technology Urgently Needs to Be Strengthened}

In the information age, it is difficult to match the update speed of information resources, technology, and hardware equipment. It is an inevitable trend to put forward higher requirements for the development of undergraduate colleges. Countries all over the world attach great importance to the popularization of information technology education and the training of primary and intermediate information technology talents, especially the training of information theory and technology for teachers. However, the teachers of undergraduate colleges are far from enough to receive information theory training. The education field has not yet formed a complete training and service system. Therefore, the faculty of the entire undergraduate colleges does not have a strong sense of informationization and a complete information technology theoretical knowledge system, and the 
ability to apply information technology is not enough to achieve the development requirements of the educational information age. In addition, teachers do not have a deep understanding of information technology and curriculum integration, low integration, and insufficient practical innovation and application capabilities, which can easily cause a simple connection between information technology and subject teaching content, resulting in low teaching utilization, software and hardware resources, and high availability of information teaching Difficult to implement effectively (Fu \& Li, 2021).

The overall information technology ability and information literacy of teachers in our country's undergraduate colleges are relatively low, and the effect of applying it to teaching is not obvious. The author learned through interviews with teachers that many teachers said that they have not received professional information teaching theory and skills training. Both young and middle-aged teachers lack systematic learning of their related theoretical knowledge. There are still some shortcomings in the courseware and computer-specific operating technology. Teachers' theoretical flaws are reflected in their low information literacy, and their inadequate technical application undoubtedly does not help English teaching, even affects students' learning effects, and cannot effectively play the role of "teacher-student learning community" in the classroom to affect teaching quality improvement. The results of the survey data show that English teachers often use network teaching methods in the classroom, the popularity of computers is not enough, and the teachers' ability to apply information technology needs to be strengthened. In addition, undergraduates did not respond to the use of information technology equipment by English teachers. It shows that teachers account for $67.40 \%$ of students with insufficient skills in using information technology equipment. These data show that teachers' information technology capabilities are insufficient, the application of information technology is more formal, and students have knowledge interaction in the classroom. The spread creates huge resistance.

\subsection{Insufficient Innovation of English Teaching Mode and Poor Teaching Methods}

The goal of undergraduate colleges is to cultivate future-oriented international talents (Dashtestani, 2016). The core lies in classroom teaching, and classroom teaching is the lifeline to measure the effectiveness of teaching. The most important thing for studying English information teaching in colleges and universities is the innovation of teaching models and methods. We need to change the traditional teacher-centered teaching model of instilling language knowledge into an English classroom teaching model with students as the main body, teachers as the leading role, and information technology as the intermediary. Reforming existing teaching methods will lay a solid foundation for cultivating students' autonomy and language application ability. The data results show that about $64.30 \%$ of students are dissatisfied with the informatization teaching carried out by the school's English teachers. It can be seen that the students' feedback on the 
implementation of informatization teaching is average. Although undergraduate colleges and universities have used computers and other multimedia technologies to assist English teaching, teachers in classroom teaching are more responsible for projecting the knowledge stored in the computer onto the big screen. In order to achieve the effective integration of information technology and English courses, there is a lack of bilateral activities in the classroom, and there is a lack of communication between teachers and students. In order to complete the teaching plan, the teacher even presents more information on the teaching equipment, ignoring the fact that the students' attention in the classroom is difficult to concentrate for a long time, which makes it difficult for the students to keep up with the rhythm of classroom teaching. Under this teaching mode, it is difficult for students to improve their learning autonomy, which leads to a decline in learning efficiency and affects the improvement of teaching quality.

\subsection{The Structure of English Informatization Teaching Content Needs to Be Improved}

At this stage, under the premise of improving the quality of running schools, undergraduate colleges and universities are also following the development trend of the information age and are committed to optimizing subject teaching. Relying on the advantages of modern information technology, update education and teaching concepts, deepen education and teaching reform, gradually realize the sharing of high-quality educational resources, and vigorously promote the process of English informatization teaching. However, there are still outstanding problems in the content of English subject informatization teaching. According to the results of the survey data, students generally believe that in the process of English learning, their listening, reading, and speaking expectations need to be improved; English songs and movies are very attractive. However, when carrying out information-based English teaching, teachers have not found suitable teaching methods to improve students' interest in English cultural background knowledge and language grammar knowledge points (Read \& Kukulska-Hulme, 2015). On the one hand, the extreme lack of high-quality subject teaching resources affects the expansion of teaching content and teaching progress; on the other hand, teachers fail to grasp the students' learning needs, hobbies and cognitive characteristics, and use the learning content as the starting point for students' interest to combine text, graphics, animation, sound and other information, establish a certain internal logical connection, and realize information interaction transfer. Under the background of higher education informationization, undergraduate English teaching is dynamic and non-linear. Its informatization teaching content does not combine with the background of the times. At present, there has not been a reasonable way to display large-capacity, high-efficiency, and completely open teaching content. There is a simple connection between traditional English classroom teaching content and information technology, which lacks diversity, integration and integration. 


\section{Countermeasures to Optimize English Teaching under the Constraints of Information Literacy of College Students in the New Era}

In order to optimize the development of English informatization teaching in undergraduate colleges, combining the research status at home and abroad and the investigation of the current situation of English informatization teaching in undergraduate colleges, we can make a reasonable reference for the development of informatization. In developed countries, regions and high levels Higher education in universities. The successful practical experience in construction and other aspects reveals its enlightenment for the cultivation of high-level talents in our country's undergraduate colleges, promotes the development of English teaching informatization, and provides sufficient basis for the proposed countermeasures, mainly involving the following aspects: Pay attention to the construction of software and hardware, adjust the proportion of hardware construction, build new learning models and methods on this basis, improve teacher training and gradually improve the construction of network courses and network resources; Attach importance to the informatization of teaching management, innovate the mechanism, integrate and improve a scientific and reasonable organizational system; Unify planning, integrate resources, reduce waste, strengthen management, improve services, and increase effective network utilization; Introduce education management professionals and computer professionals, enrich the teaching staff, the government pays attention and policy guidance; Strengthen the operating mechanism of distance education and narrow the education gap; Lifelong learning, optimizing educational information resources, and establishing a platform for information sharing and use mechanisms; Establish and improve the information technology system for higher education evaluation. Summarize the successful experience of the development of higher education informatization in developed countries, regions and high-level universities, and provide sufficient reference for the development of Chinese college English informatization teaching. While drawing on foreign advanced management experience and measures, domestic colleges and universities should boldly innovate and explore in accordance with their own actual conditions, and strive to make undergraduate colleges and universities avoid detours and make breakthroughs on the road of cultivating high-quality talents and higher education informatization. Therefore, while drawing on foreign advanced experience, combined with actual research, it provides a sufficient basis for optimizing college language information teaching strategies.

While optimizing the evaluation mechanism, undergraduate colleges and universities should also set up a special information teaching management department to institutionalize the specific requirements and regulations of language information teaching. For this reason, the implementation of informatized English teaching is also an effective obstacle to the effective development of informatization teaching in colleges and universities, in order to promote the ef- 
fective integration of information technology and teacher English courses, and better serve the education cause. It is not only a simple splicing of computers, multimedia and other equipment with English classroom teaching content, but also a reasonable and effective use of information perspective and network thinking to promote English teaching. We cannot ignore the subject status of students in the classroom because of the change in teaching methods. Improper use of information technology tools will only make teachers in the classroom a dedicated "announcer" and "announcer", and only use computers and multimedia instead of blackboards, resulting in poor cohesion of teaching content, insufficient clarity, and lack of classroom content. Therefore, optimizing the evaluation mechanism, establishing and perfecting departments and system guarantees will restrict, supervise and promote the development of informatized English teaching, which will help improve and improve the teaching quality of undergraduate colleges and universities.

The relevant results of this research are mainly derived from the actual classroom teaching experience in the past three years, and the relevant results have been promoted and applied in relevant colleges and universities. Application feedback shows that foreign language teachers pay more attention to the innovation of college English teaching concepts, and have established a hierarchical and classified training system and a hierarchical and classified curriculum system. Constructed a multi-dimensional interactive classroom environment, improved the information technology literacy of teachers and students. Effectively adjust the roles of teachers and students in the classroom, which is more conducive to the development of an equal and harmonious teacher-student relationship, and can promote the creation of a harmonious and efficient ecological classroom.

\section{Conclusion}

This article starts from the author's years of work and scientific research practice accumulation, starting from the impact of information technology on various industries, and the research framework is positioned to capture the impact of big data brought about by the rapid emergence of the Internet. Although domestic universities have made certain achievements in the reform of English teaching, due to the profound influence of traditional teaching concepts and teaching models, the protagonist of the college English classroom is still a teacher, and students are always in a passive learning state, "rote memorizing" classroom teaching methods severely restrict the development of communicative competence. There is less and less communication between students and teachers, resulting in a lack of opportunities for contextual practice, which cannot stimulate students' enthusiasm for learning English, reduce the quality of college English teaching, and cause serious obstacles to the cultivation of social English talents. Objectively, this has resulted in the social status quo in which college students' information literacy is restricted by their foreign language ability. With the rapid development of the information age represented by artificial intelligence, the 
level of college English teaching is seriously lagging behind and needs to be further improved and closely linked to the general trend of information development. Today's college students have been born in the $21^{\text {st }}$ century after 00 as the main body. They are living in a more advanced era, so their English quality and growth environment are very different from those of previous educators, and they have strong information quality. We should make good use of this advantage in the process of foreign language teaching.

\section{Conflicts of Interest}

The author declares no conflicts of interest regarding the publication of this paper.

\section{References}

Dashtestani, R. (2016). Moving Bravely towards Mobile Learning: Iranian Students' Use of Mobile Devices for Learning English as a Foreign Language. Computer Assisted Language Learning, 29, 815-832. https://doi.org/10.1080/09588221.2015.1069360

Fu, H., \& Li, F. (2021). Optimizing the Construction of College English Mobile Teaching Oriented by Industry Demand. Creative Education, 12, 737-746. https://doi.org/10.4236/ce.2021.124052

Hamidi, H., \& Chavoshi, A. (2018). Analysis of the Essential Factors for the Adoption of Mobile Learning in Higher Education: A Case Study of Students of the University of Technology. Telematics and Informatics, 35, 1053-1070.

https://doi.org/10.1016/j.tele.2017.09.016

Ma, W., \& Zhang, J. (2021). Application of Blended Teaching Mode in Comprehensive English Course. Creative Education, 12, 647-652.

https://doi.org/10.4236/ce.2021.123044

Read, T., \& Kukulska-Hulme, A. (2015). The Role of a Mobile App for Listening Comprehension Training in Distance Learning to Sustain Student Motivation. Journal of Universal Computer Science, 21, 1327-1338.

Hao, S., Dennen, V. P., \& Li, M. (2017). Influential Factors for Mobile Learning Acceptance among Chinese Users. Educational Technology Research \& Development, 65, 101-123. https://doi.org/10.1007/s11423-016-9465-2

Smit, R., \& Engeli, E. (2015). An Empirical Model of Mixed-Age Teaching. International Journal of Educational Research, 74, 136-145. https://doi.org/10.1016/j.ijer.2015.05.004

Sun, Z., Lin, C. H., You, J. et al. (2017). Improving the English-Speaking Skills of Young Learners through Mobile Social Networking. Computer Assisted Language Learning, 30, 304-324. https://doi.org/10.1080/09588221.2017.1308384

Sun, Z., Yao, X., You, J. et al. (2018). Detecting the Correlation between Mobile Learning Behavior and Personal Characteristics among Elementary School Students. Interactive Learning Environments, 26, 1-16. https://doi.org/10.1080/10494820.2018.1428633

Wang, Y., \& Ma, X. (2020). Research on Blended Teaching Ability of College English Teachers. Open Journal of Social Sciences, 8, 308-319. https://doi.org/10.4236/jss.2020.812025

Wen, Q. F. (2018). Production-Oriented Approach in Teaching Chinese as a Second Language. Chinese Teaching in the World, 3, 387-400.

Wu, Y. (2020). The Application of the POA in College English Teaching. Open Journal of Modern Linguistics, 10, 70-81. https://doi.org/10.4236/ojml.2020.101005 